\title{
SOSIALISASI AKUNTANSI "THE BUSINESS COST ACCOUNTING FOR PRODUCTS” KERUPUK KANGKUNG DESA DAPET KECAMATAN BALONGPANGGANG
}

\author{
Suwandi ${ }^{1}$, Andi Rahmad Rahim ${ }^{2}$, Rey Ajeng Wulandari ${ }^{3}$, Rossalia Hilda Safitri ${ }^{4}$, M. Alfian Hadi \\ Firmansyah $^{5}$, Nur Kholifah ${ }^{6}$ \\ ${ }^{1}$ Dosen Program Studi Akuntansi, Universitas Muhammadiyah Gresik \\ ${ }^{2}$ Dosen Program Studi Akuakultur, Universitas Muhammadiyah Gresik \\ 3,4,5,6 Mahasiswa Program Studi Akuntansi, Universitas Muhammadiyah Gresik \\ Email : hilsarossa45@gmail.com, reyajeng33@gmail.com
}

\begin{abstract}
ABSTRAK
Secara administratif, Desa Dapet terletak di wilayah Kabupaten Gresik tepatnya di Kecamatan Balongpanggang. Wilayah Desa Dapet terdiri dari 3 Dusun yaitu; Dusun Dapet, Dusun Sugihwaras, dan Dusun Kedungdowo yang masing-masing dipimpin oleh seorang Kepala Dusun. Potensi wilayah Desa Dapet mayoritas penduduknya berprofesi sebagai petani, dan perekonomian warga desa juga dari hasil pertanian atau kegiatan bercocok tanam, tanaman yang dihasilkan seperti tebu, padi, kangkung dan palawija. Untuk mewujudkan potensi desa agar semakin berkembang, mahasiswa KKN Tematik Tim 6 di Desa Dapet mempunyai ide kreatif dengan menciptakan produk unggulan yang menjadi ciri khas dari desa, dengan memanfaatkan sayuran kangkung menjadi kerupuk kangkung yang berkualitas dan mampu bersaing. Karenanya agar dapat memanfaatkan peluang yang ada di pasar, harga dari produk haruslah sesuai dengan kualitas dan kemampuan konsumen yang menjadi target penjualan. Dengan ini mahasiswa Program Studi Akuntansi KKN Tematik Tim 6 melaksanakan Sosialisasi Akuntansi "The Business Cost Accounting For Products” Kerupuk Kangkung Desa Dapet Kecamatan Balongpanggang. Kegiatan sosialisasi dilaksanakan di Balai Desa Dapet bersamaan dengan acara PKK Desa Dapet. Dalam sosialisasi tersebut ibu-ibu PKK diberikan pengetahuan dan pemahaman terkait cara menentukan harga jual suatu produk dengan modal penghitungan pembiayaan secara rinci. Hasil dari kegiatan tersebut adalah dapat menciptakan produsen baru yang paham mengenai akuntansi pembiayaan usaha melalui penjualan produk kerupuk kangkung berkualitas modern. Sebaiknya kegiatan tersebut dapat dilaksanakan dalam jangka panjang oleh Tim Penggerak PKK sehingga dapat mendorong dan menumbuhkan wirausaha baru di Desa Dapet.
\end{abstract}

Kata Kunci: Produk, Wirausaha, Business Cost Accounting 


\section{PENDAHULUAN}

\section{A. Latar Belakang}

Desa Dapet merupakan salah satu desa di Kecamatan Balongpanggang yang dipilih sebagai tempat pelaksanaan Kuliah Kerja Nyata (KKN) Tematik 2019 Universitas Muhammadiyah Gresik. Adapun waktu pelaksanaannya selama 40 hari mulai dari tanggal 26 Juli sampai dengan 20 Oktober 2019 tepatnya setiap hari jum'at, sabtu, dan minggu dalam satu minggu setiap bulannya. Secara administratif, Desa Dapet terletak di wilayah Kabupaten Gresik. Wilayah Desa Dapet terdiri dari 3 Dusun yaitu; Dusun Dapet, Dusun Sugihwaras, dan Dusun Kedungdowo yang masing-masing dipimpin oleh seorang Kepala Dusun. Desa Dapet berpotensi dalam banyak hal, dari segi potensi alam, tanah desa ini cukup baik untuk ditanami tumbuhan apapun, baik berupa padi, sayuran, maupun palawija.

Dalam 3 bulan terakhir, tanaman yang menjadi primadona petani di Desa Dapet adalah sayuran kangkung. Sayuran kangkung yang biasa dimanfaatkan bijinya saja, kini untuk lebih bernilai jual maka perlu memanfaatkan bagian lain yang lebih menjanjikan juga, yaitu daunnya yang dapat dijadikan sebagai bahan utama produk olahan kerupuk kangkung yang lebih inovatif. Produk unggulan tersebut hasil interpertasi dari mahasiswa KKN Tematik Tim 6 di Desa Dapet. Karenanya dalam mewujudkan potensi desa agar semakin berkembang, produk unggulan yang menjadi ciri khas desa harus dapat dikenal dan diakui masyarakat terutama penduduk luar desa.

Dalam hal ini masyarakat Desa Dapet dapat memafaatkan sumber daya yang ada sebagai sarana untuk berwirausaha dan membuat suatu produk inovatif lokal yang bernilai jual tinggi, dengan mengubah sayuran kangkung menjadi produk yang berkualitas dan mampu bersaing. Berwirausaha menjadi salah satu pekerjaan yang banyak dilakukan oleh masyarakat Indonesia. Wirausaha adalah seseorang yang berani mengambil risiko dan melihat peluang sebuah usaha. Ada banyak keuntungan yang bisa didapatkan dengan melakukan wirausaha, salah satunya menciptakan lapangan kerja baru bagi orang lain. Saat ini pemerintah juga sangat mendukung setiap orang yang berani untuk berwirausaha.

Wirausaha yang kompeten adalah yang memahami dan mengerti proses transaksi dan keuangan dengan benar. Salah satunya dalam menentukan dan menetapkan harga untuk produk yang dijual. Untuk menentukan penentuan harga pokok atas suatu produk atau jasa yang dihasilkan oleh perusahaan digunakan fungsi Akuntansi Biaya. Dengan akuntansi biaya, maka harga yang ditawarkan tidak terlalu tinggi ataupun terlalu rendah oleh konsumen. Penentuan harga pokok diperoleh dengan cara mencatat, menggolongkan, memonitor, dan meringkas seluruh komponen biaya yang berhubungan dengan proses produksi dari data histori yang 
dijadikan acuan pihak yang mengolah bisnis (manajemen) dalam penentuan harga pokok produksi.

Dasar yang digunakan dalam estimasi biaya adalah data histori dengan mempertimbangkan faktor-faktor lain yang diprediksi akan memengaruhi biaya. Dalam perencanaan dan pengendalian biaya, pihak manajemen akan memonitor apakah terjadi penyimpangan (ada selisih antara biaya sesungguhnya dengan perencanaan biaya). Jika ada, pihak manajemen akan menganalisis penyebab terjadinya selisih serta mempertimbangkan tindakan koreksi yang memang perlu dilakukan sebagai bentuk pengendalian. Oleh karena itu, Akuntansi Biaya merupakan bagian penting dari penghitungan pembiayaan produksi yang akan berdampak pada kelangsungan produksi dan penentuan masa depan strategi usaha.

Untuk pengetahuan bagi warga Desa Dapet terutama ibu-ibu PKK yang berkeinginan memulai suatu usaha perlu adanya Sosialisasi Akuntansi "The Business Cost Accounting For Products" yang dalam bahasa Indonesia adalah akuntansi pembiayaan usaha dari produk yang diperdagangkan merupakan suatu hal yang amat sangat dibutuhkan. Karena dengan adanya pengetahuan terkait Akuntansi Biaya dalam memulai bisnis, maka ilmu yang mempelajari tentang penyediaan informasi dibutuhkan suatu akuntansi keuangan dan menajemen suatu usaha. Kehadiran Akuntansi Biaya dapat mengukur serta melaporkan infromasi baik yang berkaitan dengan keuangan maupun non keuangan, yang berkaitan dengan biaya yang diperoleh serta pemanfaatan dari sumber daya dalam sebuah organisasi.

\section{B. Tujuan}

Sosialisasi Akuntansi "The Business Cost Accounting For Products" bermaksud untuk memudahkan ibu-ibu PKK dalam menentukan harga jual dari suatu produk, yaitu kerupuk kangkung. Dengan tujuan untuk memberikan suatu pengetahuan, pemahaman, dan pengarahan terkait penentuan harga pokok atas suatu produk atau jasa yang dihasilkan oleh perusahaan dengan fungsi Akuntansi Biaya.

Sasaran dari kegiatan Sosialisasi Akuntansi "The Business Cost Accounting For Products" adalah warga desa terutama ibu-ibu PKK di Desa Dapet, yang memiliki jiwa wirausaha dan berkeinginan dalam menambah ilmu guna kelangsungan produksi dan penentuan masa depan strategi usahanya. 


\section{Manfaat}

Manfaat dari kegiatan Sosialisasi Akuntansi “The Business Cost Accounting For Products”, yaitu:

1. Memberikan kesadaran kepada masyarakat bahwa wirausaha itu penting dan menjanjikan,

2. Membudayakan perilaku, sikap, kemampuan, dan semangat untuk menjadi wirausahawan,

3. Dapat memajukan dan menyejahterakan masyarakat, serta

4. Meningkatkan jumlah wirausaha dengan kualitas yang baik.

\section{METODE}

Untuk mendukung kelancaran dan terlaksananya program kerja Sosialisasi Akuntansi The Business Cost Accounting For Products Kerupuk Kangkung, metode yang digunakan meliputi:

1) Koordinasi dan Persiapan Program Kerja

Koordinasi program kerja Prodi Akuntansi, yaitu Sosialisasi Akuntansi The Business Cost Accounting For Products, dilaksanakan saat pembukaan KKN di Balai Desa Dapet bersama Kepala Desa, perangkat, dan ibu ketua PKK Desa Dapet. Koordinasi ini dimaksudkan untuk memastikan waktu dan tempat pelaksanaan program kerja.

Setelah melakukan koordinasi dengan ibu ketua PKK Desa Dapet, dilakukan persiapan untuk menyiapkan segala sesuatu yang dibutuhkan untuk merealisasikan program kerja seperti menyusun dan mempersiapkan contoh pencatatan dan penentuan akuntansi pembiayaan usaha kerupuk kangkung.

2) Sosialisasi

Sosialisasi Akuntansi "The Business Cost Accounting For Products" Kerupuk Kangkung, dijelaskan bahwa penentuan harga produk yang akan diperdagangkan bukan hanya dengan ilmu perkiraan tetapi ada rumus dan cara sendiri dengan perhitungan akuntansi.

Melalui sosialisai ini dijelaskan cara awal perhitungan dari jumlah bahan baku, kemudian bagaimana cara menghitungnya dengan perhitungan sederhana jika menerapkan ilmu akuntasi di dalamnya. Sehingga dengan adanya sosialisasi ini menghasilkan pengetahuan yang luas tentang harga jual produk jadi yang akan diperdagangkan sebagai seorang wirausahawan.

3) Monitoring Kegiatan

Monitoring kegiatan bertujuan untuk mengetahui perkembangan dari penerapan program kerja Sosialisasi Akuntansi "The Business Cost Accounting For Products" Kerupuk Kangkung. Dalam kegiatan monitoring ini dilakukan saat acara perkumpulan serta 
rapat ibu-ibu PPK Desa Dapet dan mendapat hasil yang cukup bagus dengan ibu-ibu PPK sudah sedikit menerapkan perhitungan ilmu akuntansi pada produk dagangan yang mereka miliki.

\section{A. Waktu dan Tempat}

Waktu dan tempat pelaksanaan program kerja Prodi Akuntansi, Sosialisasi Akuntansi The Business Cost Accounting For Product, antara lain:

1) Koordinasi

$$
\begin{aligned}
& \text { Hari : Minggu } \\
& \text { Tanggal : } 28 \text { Juli } 2019 \\
& \text { Pukul : } 10.00 \text { - selesai } \\
& \text { Tempat : Balai Desa Dapet } \\
& \text { Persiapan } \\
& \text { Program Kerja }
\end{aligned}
$$

Tanggal : 22 September 2019

Pukul : 09.00 - selesai

Tempat : Rumah Ketua PKK Desa

Dapet

2) Sosialisasi

Hari : Sabtu

Tanggal : 05 Oktober 2019

Pukul : 16.30 - selesai

Tempat : Balai Desa Dapet

3) Monitoring Kegiatan

Hari : Sabtu

Tanggal : 12 Oktober 2019

Pukul : 16.30 - selesai

Tempat : Balai Desa Dapet

\section{HASIL DAN PEMBAHASAN}

Pelaksanaa dan pelatihan dilasanakaan secara langsung saat sosialisasi The Business Cost Accounting For Product bersama ibu-ibu PPK di Balai Desa Dapet dengan cara mengambil contoh dari perhitungan produk kerupuk kangkung yang sebelumnya diproduksi oleh kelompok 
KKN Tematik 6, agar ibu-ibu PKK di Desa Dapet mendapat mengetahuan secara langsung penerapan perhitungannya dan bukan sekedar sosialisasi biasa tanpa menerapkan praktek.

Dengan cara ini memudahkan ibu-ibu PPK untuk lebih memahami program kerja yang kita lakukan yaitu sosialisasi The Business Cost Accounting For Product kerupuk kangkung. Selain itu, dalam kegiatan monitoring program kerja dilakukan forum yang nantinya diadakan tanya jawab bagi ibu-ibu kurang memahami penetapan harga pokok produk ini.

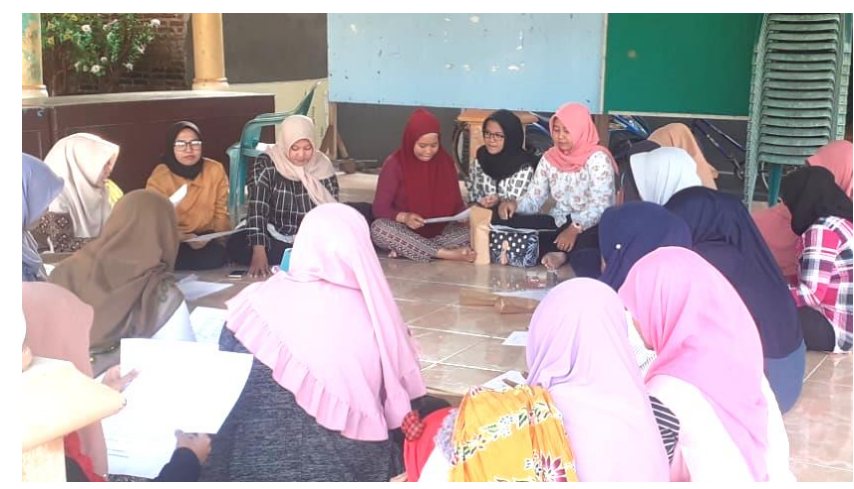

Gambar 1. Pengarahan Penentuan Akuntansi Biaya

Hasil yang didapatkan cukup bagus dengan adanya ibu-ibu PPK sudah sedikit menerapkan Perhitungan ilmu akuntansi pada produk dagangan yang mereka miliki.

Penentuan harga jual ini mereka terapkan bukan hanya pada produk-produk yang dimiliki organisasi PPK sendiri melainkan juga pada usaha mereka masing-masing. Tetapi yang menjadi ganjalan dalam proses perhitungan adalah untuk mengingat rumus sederhana itu sendiri karna dampak dari minimnya pengetahuan mereka.

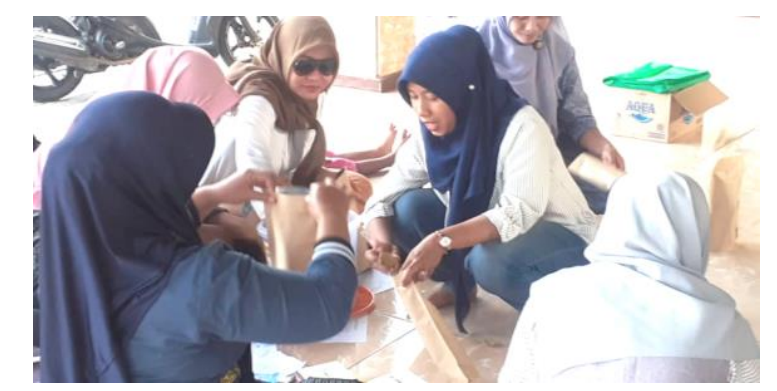

Gambar 2. Pembagian Sampel Kerupuk Kangkung 


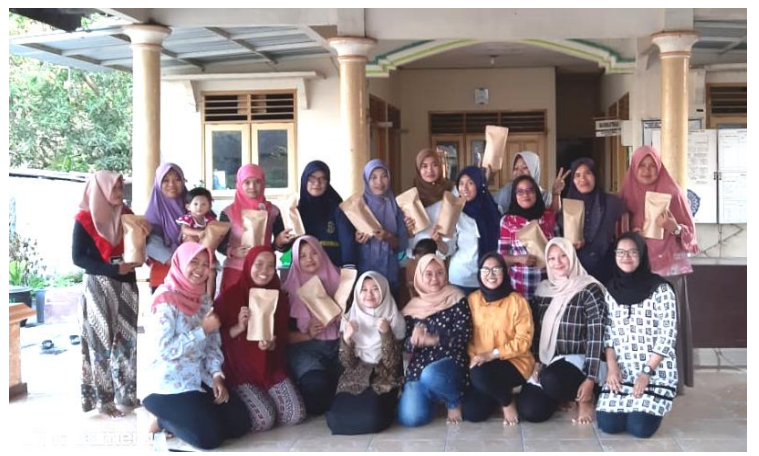

Gambar 3. Sosialisasi Akuntansi Biaya suatu Produk

\section{KESIMPULAN DAN SARAN}

\section{A. Kesimpulan}

Dalam memperdagangkan produk kebanyakan ibu-ibu Desa Dapet terutama masih minim pengetahuan tentang perhitungan harga jual, apalagi dengan menggunakan ilmu akuntansi. Kebanyakan dari mereka hanya saja menerapkan ilmu perkiraan dari jumlah bahan baku kemudian ditentukan harga jual suatu produk

Maka, dengan adanya sosialisasi ini para ibu-ibu yang ada di Desa Dapet lebih luas pengetahuan dan pemahaman tentang penentuan harga pokok atas produk maupun jasa yang dihasilkan. Dan memiliki sikap prilaku seperti wirausahawan karena wirausaha dimasa sekarang cukup menjanjikan bagi ibu-ibu rumah tangga, jadi sangatlah perlu perhitungan yang benar.

\section{B. Saran}

Dalam menjalankan usahanya diharapkan ibu-ibu di Desa Dapet lebih banyak mencari mengetahuan dan pemahaman untuk proses usahanya yang lebih berkembang. Karna suatu perhitungan produk yang kita pasarkan sangatlah berpengaruh pada perkembangan dan kemajuan usaha itu sendiri.

Jadi bukan hanya sedekar menggunakan ilmu perkiraan untuk menjalankan usaha tetapi harus menerapkan perhitungan yang seharusnya dipakai dari perhitungan menentukan harga pokok produk, perhitungan akuntansi laba rugi, dan lain sebagainya.

\section{DAFTAR PUSTAKA}

Novia. (2017). Akuntansi Biaya dan Klasifikasinya. Diakses pada tanggal 22 Oktober 2019. https://www.jurnal.id/id/blog/2017-pengertian-akuntansi-biaya-fungsi-danklasifikasinya/html. 


\section{DedikasiMU (Journal of Community Service)}

Volume 2, Nomor 1, Maret 2020

Rahim A.R, Bela ND, Mutmainnah M, Araswati Z. (2019). Sosialisasi Dan Implementasi Pembuatan Krupuk Ikan Bandeng Desa Karanggeneng Kec. Karanggeneng Kab. Lamongan. Jurnal DedikasiMU. Vol 1. No 1. pp 1-10.

Rahim A.R. (2018) Pemanfaatan Limbah Tambak Ikan Untuk Budidaya Cacing Tanah Lumbricus rubellus. Jurnal Perikanan Pantura (JPP). Vol 2. No 1. pp. 1-8.

Rahim A.R. (2018). Application of Seaweed Gracilaria verrucosa Tissue Culture using Different Doses of Vermicompost Fertilizer. Nature Environment and Pollution Technology. Vol 17. pp.661-665.

Rahim A.R., Herawati E.Y., Nursyam H., Hariati AM. (2016). Combination of Vermicompost Fertilizer, Carbon, Nitrogen and Phosphorus on Cell Characteristics, Growth and Quality of Agar Seaweed Gracilaria verrucosa. Nature Environment \& Pollution Technology. Volume 15, No. 4.

Rahim A.R., Ruhumuddin S, Rosmarlinasiah. (2019). Productivity Improvement of Milkfish and Seaweed Polyculture using Vermicomposting Fertilizer from Sources of Waste. International Journal of Recent Technology and Engineering. Volume-8 Issue-3. pp 1377-1381. 